\title{
Sorption of carbon dioxide on the lithotypes of low rank coal
}

\author{
Katarzyna Czerw ${ }^{1}\left[\right.$. Agnieszka Dudzińska ${ }^{2} \cdot$ Paweł Baran $^{1} \cdot$ Katarzyna Zarębska $^{1}$
}

Received: 17 October 2018 / Revised: 18 April 2019 / Accepted: 20 May 2019 / Published online: 29 May 2019

(c) The Author(s) 2019

\begin{abstract}
The aims of this work were (1) the determination of the efficiency of isolating by hand two lithotypes concentrates, vitrain and durain, from original coal sample of low rank bituminous coal, (2) the evaluation of the relation between macro- and microscopically distinguishable components of samples under investigation and their physicochemical properties and (3) the assessment of the effect of maceral composition of low rank coal on carbon dioxide sorption capacity and desorption process. To address the first issue a petrographic analysis was performed for separated components and the original raw sample. A significantly higher vitrinite content in vitrain concentrate and much lower in durain concentrate in regard to basic coal confirmed that the separation process was satisfactory. The second aspect comprised an investigation into selected physical and chemical properties of original coal and two lithotypes concentrates including helium density, methanol density, FTIR spectra, the amount of oxygen functional groups and swelling properties using pyridine as solvent. The results show that in the case of material under study the coal rank does not preponderate the effect of maceral composition. This third issue was addressed by performing adequate sorption experiments carried out at $298 \mathrm{~K}$ at low pressure on basic coal sample and two lithotypes concentrates. The tendency of adsorption capacity of $\mathrm{CO}_{2}$ to depend on maceral composition was confirmed as it increases with the content of vitrinite. The Dubinin-Radushkevich equation shows a very good agreement with all the experimental data obtained for both lithotypes concentrates and basic coal under investigation.
\end{abstract}

Keywords Hard coal · Coal lithotypes · Coal macerals · Carbon dioxide sorption · Dubinin-Radushkevich isotherm

\section{Introduction}

Coal is a solid carbon-rich material, usually brown or black, that most often occurs in stratified sedimentary deposits. Different varieties of coal arise from two main issues: differences in the kinds of plants that became a base organic material for the formation of coal deposits and the degree to which coals have undergone coalification process. The complexity and heterogeneity of coal is the most persistent problem in discussing any topic in coal science.

This article belongs to S.I. ISSHAC10, but it reach the press at the time the special issue was published.

Katarzyna Czerw

kczerw@agh.edu.pl

1 Faculty of Energy and Fuels, AGH University of Science and Technology, Aleja Mickiewicza 30, 30-059 Krakow, Poland

2 Mines Ventilation Department, Central Institute of Mining, Plac Gwarków 1, 40-166 Katowice, Poland
Coals may be classified on the basis of their macroscopic appearance (Bielowicz 2012; O'Keefe et al. 2013). One of the basic systematic includes four main types of macroscopically distinguishable components called lithotypes. On the microscopic scale the term macerals describes an organic constituents present in coals and three major maceral groups are recognized: vitrinite, liptinite and inertinite (O'Keefe et al. 2013). Vitrain (bright coal) was probably formed under drier surface conditions than the other lithotypes and on burial, stagnant groundwater prevented the complete decomposition of the woody plant tissue. It is composed primarily of the maceral group vitrinite, derived from cell walls of the bark (woody) tissue of large plants. Durain on the other hand is a dull coal thought to have formed in peat deposits below water level, where only liptinite and inertinite resisted decomposition and where inorganic minerals accumulated from sedimentation. In general, liptinites are derived from waxy or resinous plant parts and inertinites are derived from strongly altered or degraded plant material produced during the formation of peat. Clarain has an appearance between those of vitrain and durain and it seems 
to have originated under conditions that alternated between those in which durain and vitrain were formed. Fusain is composed mainly of fusinite that is a highly carbonized woody plant tissue and semifusinite from the maceral group inertinite. It is believed to have been formed in intense heat conditions like in peat deposits swept by fires, by fungal activity or by subsurface oxidation.

Coal lithotypes differ in their maceral composition and typically, there is an increase of inertinite and a decrease in vitrinite content from vitrain to fusain (Mastalerz et al. 2010; Teng et al. 2017). This results in differing physical and chemical properties of lithotypes. Inertinite and liptinite have a greater percentage of mesoporosity and less microporosity than vitrinite obtained from the same coal or coals of the same rank (Clarkson and Bustin 1999). What is important in the aspect of adsorption, there are significant differences in porosity characteristics, pore volume distributions and adsorption characteristics. Teng et al. (2017) investigated porosity characteristics in three Pennsylvanian high volatile bituminous coals hand-separated into four lithotypes each: vitrain, clarain, durain, and fusain. Micropore characteristics of coal under investigation were analyzed by lowpressure $\mathrm{CO}_{2}$ adsorption showing the D-R micropore surface area and D-A micropore volume decrease from vitrain, through clarain, and durain to fusain. Among lithotypes vitrain usually have the largest adsorption capacity and fusain the smallest (Lamberson and Bustin 1993; Mastalerz et al. 2004; Mastalerz et al. 2008; Karacan and Mitchell 2003).

The diversity and complexity of potential interactions between coal and gas or vapor is a significant issue when it comes to investigations and attempts of understanding the mechanisms of accumulation of gas or vapors in coal structure (Baran et al. 2018; Busch et al. 2004; Karacan and Mitchell 2003; Zarębska and Dudzińska 2008). This investigation was inspired by the results and conclusions presented in the work of Chalmers and Bustin (2007) concerning sorption of methane on dull and bright samples extracted by hand-picking from original coals of different rank. The authors stated that the maceral composition is more important in high rank coals because even vitrinite is macroporous in low rank coals as the gas capacity for dull samples of low rank coals can be similar or higher than for their bright counterparts. Most recently Radlinski and Mastalerz (2018) published the results of SANS and USANS measurements performed on a series of six vitrinite samples having vitrinite reflectance values ranging from 0.55 (high volatile bituminous rank) to $1.28 \%$ (medium volatile bituminous rank). The appearance (shape and intensity) of SANS curves for pore size range from 1 to $25 \mathrm{~nm}$, scattering from the lowest-rank high volatile bituminous samples is drastically different from all higher-rank vitrinites, suggesting that a significant rearrangement of the maceral microstructure takes place with increasing rank.
The general purpose of this study was to answer a question: Does coal rank determine the influence of maceral composition on sorption of carbon dioxide in hard coal of a very low rank? After the evaluation of the efficiency of isolating by hand two lithotypes concentrates, vitrain and durain, from original coal sample of low rank bituminous coal, testing of the relation between macro- and microscopically distinguishable components of samples under investigation and their physicochemical properties took place. Afterwards the assessment of the effect of maceral composition of low rank coal on carbon dioxide sorption capacity and desorption process was made. The Dubinin-Radushkevich equation was used to describe the experimental data obtained for both lithotypes concentrates and basic coal under investigation.

\section{Experimental}

First step concerned test material preparation. It comprised a manual separation of a portion of original coal into two lithotypes concentrates, vitrain (sample V) and durain (sample D), and obtaining their maceral composition. Second step included preliminary tests such as proximate and ultimate analysis of basic coal (sample B) and petrographic analysis of basic coal and two lithotypes concentrates and subsequent physicochemical tests including FTIR analysis, acidic oxygen groups content, real and apparent density and pyridine swelling ratio. During third step, $\mathrm{CO}_{2}$ sorption experiments were carried out at $298 \mathrm{~K}$ at low pressure on all three samples.

Original coal samples of high volatile bituminous rank coal (according to ECE-UN In Seam Coal Classification) were obtained from "Sobieski" coal mine located in the Upper Silesia Basin in Poland form seam 207 located at the depth of $540 \mathrm{~m}$. The elemental analysis was performed in the Central Mining Institute in Katowice. The moisture content was determined in accordance with the procedure set forth in the standard PN-80/G-04511, ash content was established in accordance with PN-80/G-04512. The oxygen content was computed as the remainder of $100 \%$, taking into account the moisture and ash content (Table 1). The petrographic composition and average reflectance of vitrinite were carried out at the Department of Deposit and Mining Geology, Faculty of Geology, Geophysics and Environmental Protection (AGH University of Science and Technology), by means of a mineralogical microscope AXIOPLAN and a reflectometer Axioplan-MPM-400 made by ZEISS OPTION (Table 2). Real coal density was determined using the automated apparatus Accu Pyc 1330 (Micrometrics) and apparent coal density was determined by pycnometer using methanol as the pycnometric fluid (Table 4). 
Table 1 Specification of original coal sample B: proximate and ultimate analysis and vitrinite reflectance

\begin{tabular}{lllllllll}
\hline \multicolumn{7}{l}{ Proximate analysis } & \multicolumn{7}{c}{ Ultimate analysis } \\
\hline Parameter & $\mathrm{W}^{\mathrm{a}}[\%]$ & $\mathrm{A}^{\mathrm{a}}[\%]$ & $\mathrm{V}^{\mathrm{a}}[\%]$ & $\mathrm{C}^{\mathrm{a}}[\%]$ & $\mathrm{H}^{\mathrm{a}}[\%]$ & $\mathrm{N}^{\mathrm{a}}[\%]$ & $\mathrm{S}^{\mathrm{a}}[\%]$ & $\mathrm{O}^{\mathrm{a}}[\%]$ \\
$\mathrm{B}$ & 6.13 & 5.53 & 32.27 & 66.85 & 3.77 & 0.93 & 0.19 & 14.17 \\
\hline
\end{tabular}

$W^{a}$ moisture content, analytical basis, $A^{a}$ ash content, analytical basis, $V^{a}$ volatile matter content, analytical basis, $C^{a}$ content of element $\mathrm{C}$, analytical basis, $H^{a}$ content of element $\mathrm{H}$, analytical basis, $N^{a}$ content of element $\mathrm{N}$, analytical basis, $O^{a}$ content of element $\mathrm{O}$, analytical basis, $S^{a}$ content of element $\mathrm{S}$, analytical basis
Table 2 Specification of coal samples: maceral group composition

\begin{tabular}{llllll}
\hline $\begin{array}{l}\text { Vitrinite } \\
{[\%]}\end{array}$ & $\begin{array}{l}\text { Liptinite } \\
{[\%]}\end{array}$ & $\begin{array}{l}\text { Inertinite } \\
{[\%]}\end{array}$ & $\begin{array}{l}\text { Mineral } \\
\text { matter } \\
{[\%]}\end{array}$ & $\begin{array}{l}\text { Vitrinite } \\
\text { reflectance } \\
{[\%]}\end{array}$ \\
\hline $\mathrm{V}$ & 74.6 & 6 & 13.9 & 5.5 & 0.51 \\
$\mathrm{~B}$ & 51 & 11 & 36 & 2 & 0.51 \\
$\mathrm{D}$ & 28.4 & 16.3 & 47.2 & 8.1 & 0.51 \\
\hline
\end{tabular}

Fourier transform infrared spectrometry (FTIR) investigation was performed using Frontier MIR/FIR Spectrometer. Scans were recorded in the 400 and $4000 \mathrm{~cm}^{-1}$ wavenumber region. The FTIR analysis provides information about distribution and abundances of chemical functional groups and the relative abundance of the oxygen functional group. A comparison of the spectra obtained for samples $\mathrm{V}, \mathrm{B}$ and $\mathrm{D}$ was used to evaluate chemical differences among lithotypes.

Traditional, the so-called "Boehm titration" has been used as a chemical method to identify oxygen surface groups on coal samples under investigation. The Boehm titration is based on the principle that oxygen groups have different acidities and can be neutralized due to different strengths. Sodium hydroxide $(\mathrm{NaOH})$, the strongest base used, is assumed to neutralize all Brønsted acids (including phenols, lactonic groups and carboxylic acids), sodium carbonate $\left(\mathrm{Na}_{2} \mathrm{CO}_{3}\right)$ neutralizes carboxylic and lactonic groups (e.g. lactone and lactol rings) and sodium bicarbonate $\left(\mathrm{NaHCO}_{3}\right)$ neutralizes carboxylic acids. The difference between the uptake of the bases is used to identify and quantify the types of oxygen surface groups (Goertzen et al. 2010).

To determine the coal swelling ratio in pyridine a simple and effective technique was used. The samples (grain diameter $<0.2 \mathrm{~mm}$ ) were placed in glass narrow tubes ( $3 \mathrm{~mm}$ internal diameter, length $20 \mathrm{~cm}$ ) and their height was measured. As the goal of this test was to determine the swelling-induced volumetric changes the mass of coal used was not measured. Then solvent was added and mixed with coal to ensure that the fluid will reach every grain of coal. The tests were performed until no more changes in the samples height were observed, at least 14 days. The solvent was being refilled during the test to ensure the coverage of the coal stake surface of at least a $3 \mathrm{~cm}$ layer of fluid. The

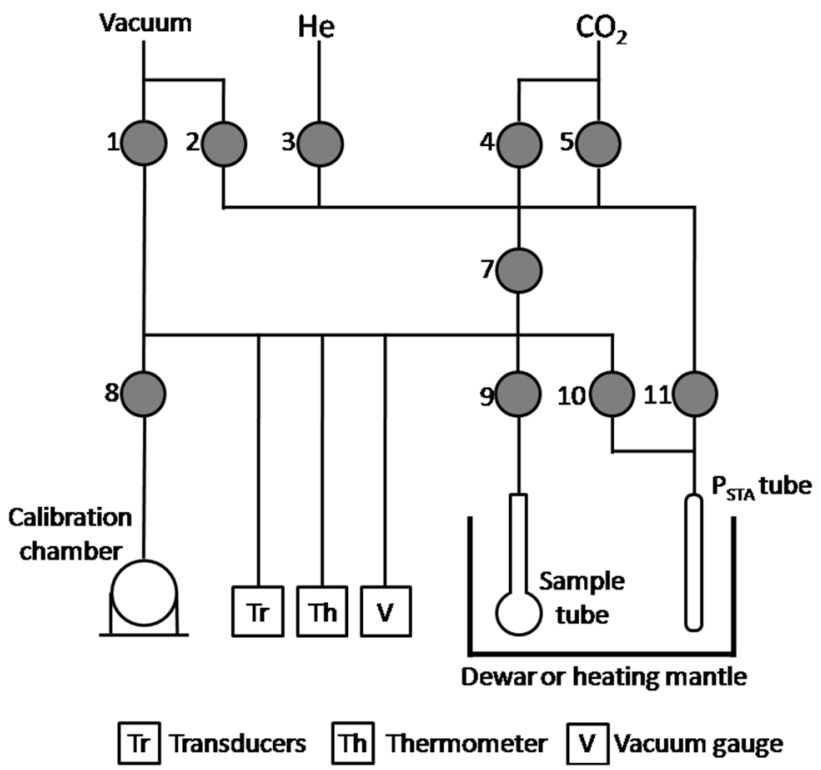

Fig. 1 Schematic of sorption apparatus

swelling ratio was the increase of coal sample height divided by the height of the original coal.

Low-pressure experimental tests of $\mathrm{CO}_{2}$ sorption were performed by the volumetric method, at the temperature of 298 K. The measurements were taken with a sorption meter ASAP 2010 (Micrometrics) (Fig. 1). The upper manifold is equipped with a set of control valves regulating the flow of sorption gases used in measurements (valves 1, 2, 3, 4, 5). The lower manifold houses the measuring equipment with valve 7 acting as the lower manifold isolation point. The calibration chamber allows for setting right the potential errors prior to measurements. The test tube containing the coal sample is connected to the upper manifold, through which the gas is added at the specified pressure. The whole tube is placed inside the heating mantle or Dewar bottle, to eliminate the temperature fluctuations.

Samples of grain diameter $<0.2 \mathrm{~mm}$ in size, weighing about $1.5 \mathrm{~g}$ were used. The procedure included the previous sample preparation by degassing the apparatus and the sample itself to secure the removal of possible interfering previously sorbed gases and vapours, including water molecules. This apparatus allows the sample to be degassed through the use of a vacuum pump in the vacuum conditions under $10^{-3}$ 
Pa. After reaching the required pressure, the system was sealed by the vacuum pump's valves 1 and 2 . Before the start of a sorption experiment, the void volume of the sample cell, i.e. the volume not occupied by the sorbent, was determined volumetrically using $\mathrm{He}$ as a non-adsorbing measuring gas. The sample tube was placed inside the heating mantle to maintain the constant temperature. After $\mathrm{CO}_{2}$ was introduced into the degassed measurement cell being added till no changes in the pressure were monitored i.e. until reaching the state of equilibrium at the selected pressure value (an equilibrium detection algorithm). This procedure was performed in a sequence of 50 pressure steps, including the desorption stages.

\section{Results}

The maceral composition of lithotype concentrates and original coal confirmed that the efficiency of separation process was sufficient (Table 2). The amount of vitrinites was increased by $23.6 \%$ in sample $\mathrm{V}$ and decreased by $22.3 \%$ in sample D when compared to the basic coal sample B. Conversely, the content of macerals of inertinite group increased by $61.4 \%$ in sample $\mathrm{D}$ and decreased by $31.1 \%$ in sample $\mathrm{V}$ in comparison to basic coal sample B.

Coal structure is a three-dimensional network containing chains of aromatic and hydroaromatic macro-units crosslinked by covalent bonds, hydrogen bonding and van der Waals interactions with lower-molecular-weight elements trapped or bonded within pore system. The term oxygencontaining functional groups refers to the chemically bound oxygen contained in coal as the organic components. In general, the obtained spectra of the original coal and concentrates of lithotypes are very similar (Fig. 2). Every sample is characterized by a broad hydroxyl region with an absorbance peak at $3422 \mathrm{~cm}^{-1}$ (Zhang et al. 2015) with sample $V$ spectra differ from those of sample D and sample B by the higher intensity of this region. The presence of hydroxyl groups on the pore surface has a strong influence on the adsorption of polar sorbates. Sample V spectra is characterized by minor prominent aliphatic band in the aliphatic stretching region (2800-3000 $\mathrm{cm}^{-1}$ ) (Teng et al. 2017) with other spectra having barely visible absorption peaks. The same situation can be observed for an aromatic carbon region (1550-1650 $\left.\mathrm{cm}^{-1}\right)$. Absorption in this band have a prominent aromatic carbon a peak at $1610 \mathrm{~cm}^{-1}$ (Ibarra et al. 1996) and is an indication of conjugated $\mathrm{C}=\mathrm{C}$ structures which occur in significantly higher numbers in the vitrinite rich sample V in comparison with sample D. Bands in the aliphatic bending region $\left(1350-1450 \mathrm{~cm}^{-1}\right.$ ) (Teng et al. 2017) are less prominent for the samples with less vitrinite content. In case of sample D the appearance of an absorption

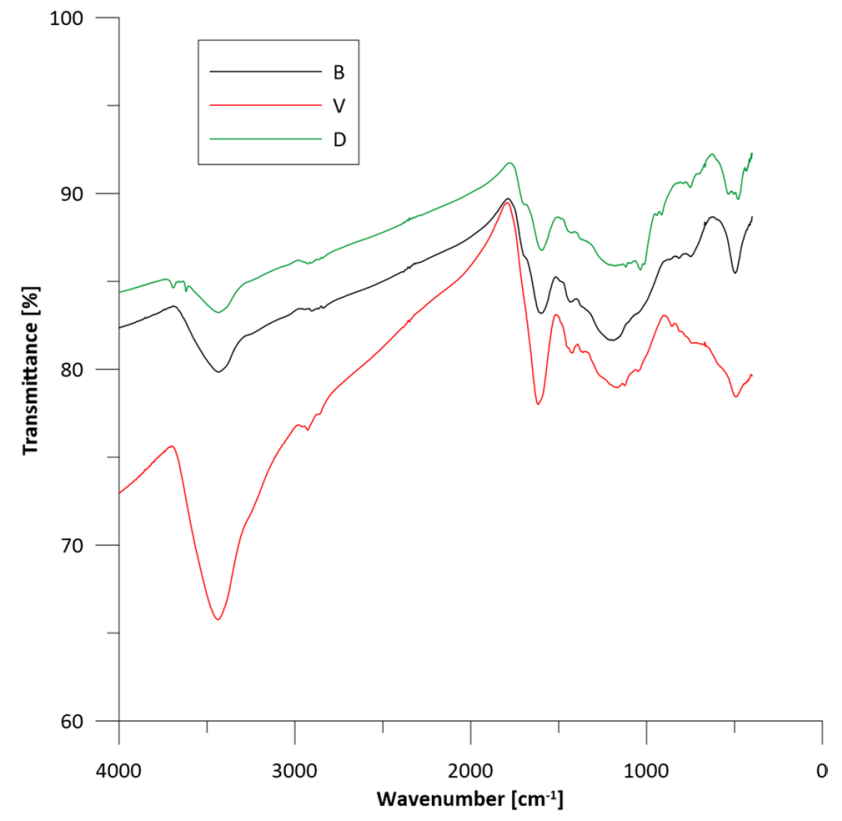

Fig. 2 FTIR spectra of samples under investigation: basic coal B, vitrain concentrate $\mathrm{V}$ and durain concentrate $\mathrm{D}$

Table 3 Acidic oxygen groups content in coal samples under investigation

\begin{tabular}{llll}
\hline & \multicolumn{2}{l}{ Group types content $[\mathrm{mol} / \mathrm{kg}]$} \\
\cline { 2 - 4 } & Phenol groups & Lactonic groups & $\begin{array}{l}\text { Car- } \\
\text { boxylic } \\
\text { groups }\end{array}$ \\
\hline V & 2.484 & - & 0.847 \\
B & 2.240 & 0.400 & 0.897 \\
D & 2.097 & 0.194 & 0.699 \\
\hline
\end{tabular}

peak at $1030 \mathrm{~cm}^{-1}$ is very likely to represent mineral matter (Zhang et al. 2015).

Oxygen groups are vital to coal surface properties, such as reactivity, hydrophilicity and hydrophobicity. The total oxygen content decreases with an increase in coal rank and differs between respective macerals groups. The results obtain in this test remain in accordance to anticipation. The higher the amount of vitrinite the higher the content of oxygen groups (Table 3).

Real density of coal is not proportional to the coal rank. This parameter decreases with the increase of rank and reaches minimal value for vitrinite maceral in coals for which the content of element $\mathrm{C}$ is about $87 \%$ (dry ash free basis). Further increase in rank results in increase of real density. Inertinite has higher and liptinite has lover density than vitrinite. The results are in accordance with the predictions based on the outcome of petrographic analysis (Table 4). 
Table 4 Real and apparent density and pyridine swelling ratio of coal samples under investigation

\begin{tabular}{llll}
\hline & $\begin{array}{l}\text { Real density }\left[\mathrm{g} / \mathrm{cm}^{3}\right] \\
\text { (helium density) }\end{array}$ & $\begin{array}{l}\text { Apparent density }\left[\mathrm{g} / \mathrm{cm}^{3}\right] \\
\text { (methanol density) }\end{array}$ & $\begin{array}{l}\text { Swelling } \\
\text { ratio [\%] }\end{array}$ \\
\hline $\mathrm{V}$ & 1.35 & 1.39 & 8.9 \\
$\mathrm{~B}$ & 1.40 & 1.48 & 3.3 \\
$\mathrm{D}$ & 1.50 & 1.55 & 2.7 \\
\hline
\end{tabular}

Coal has been compared to glassy polymers of similar structure and described as glassy, strained, cross-linked macromolecular systems that are not in their lowest energy state (Larsen et al. 1997). Likewise, because coal is viscoelastic and partly does not dissolve in solvents but swells when exposed to them. Pyridine is often used in swelling experiments on coal. This solvent enables the coal structure to transform from glassy to rubbery state (Ndaji and Thomas 1993). Surprisingly, the swelling ratio of sample V is much higher than the value of this parameter obtained for samples B and D (Table 4). Macerals of vitrinite group have the highest swelling rate and ratio and inertinite group lack this properties, except co-called reactive semifusinite (Chalmers and Bustin 2007). The presence of inertinite alongside vitrinite in basic sample seems to be blocking the effect of swelling attributed essentially to the microporous macerals of vitrinite group.

A significantly higher carbon dioxide sorption capacity was observed for vitrain concentrate than for durain concentrate with basic coal position itself in the middle (Fig. 3). At the end of sorption part of the experiment the carbon dioxide capacity of sample $\mathrm{V}$ was $22.4 \%$ higher and the carbon dioxide capacity of sample D was $21.7 \%$ lower than the value obtained for basic coal sample B. The sorption capacity of samples under investigation are similar to the values obtained for comparable coal samples of clarain and durain by Teng et al. (2017) and sample TN researched by Zhao et al. (2016).

To determine the coal specific surface area of micropores and micropore volume adsorption of $\mathrm{CO}_{2}$ at $273 \mathrm{~K}$ was performed with a Micromeritics ASAP 2010 specific surface analyzer. The results are presented in Table 5. The obtained values of both the surface area of micropores and micropore volume increase from sample D, through sample B to sample $\mathrm{V}$. In general, they are comparable with those obtained by Chalmers and Bustin (2007) for samples F82 dull and F82 bright $\left(\mathrm{R}_{\mathrm{o}} 0.5\right.$, vitrinite content $47.6 \%$ and $89.2 \%$, respectively). However, they are higher than the results of comparable tests performed on other coals of similar rank and petrographic composition: samples 2005-787-2 and 2005-787-4
Fig. 3 Low pressure $\mathrm{CO}_{2}$ sorption isotherms of the original coal $\mathrm{B}$ and isolated lithotype concentrates of vitrain $\mathrm{V}$ and durain D (eq.-Dubinin--Radushkevich equation)

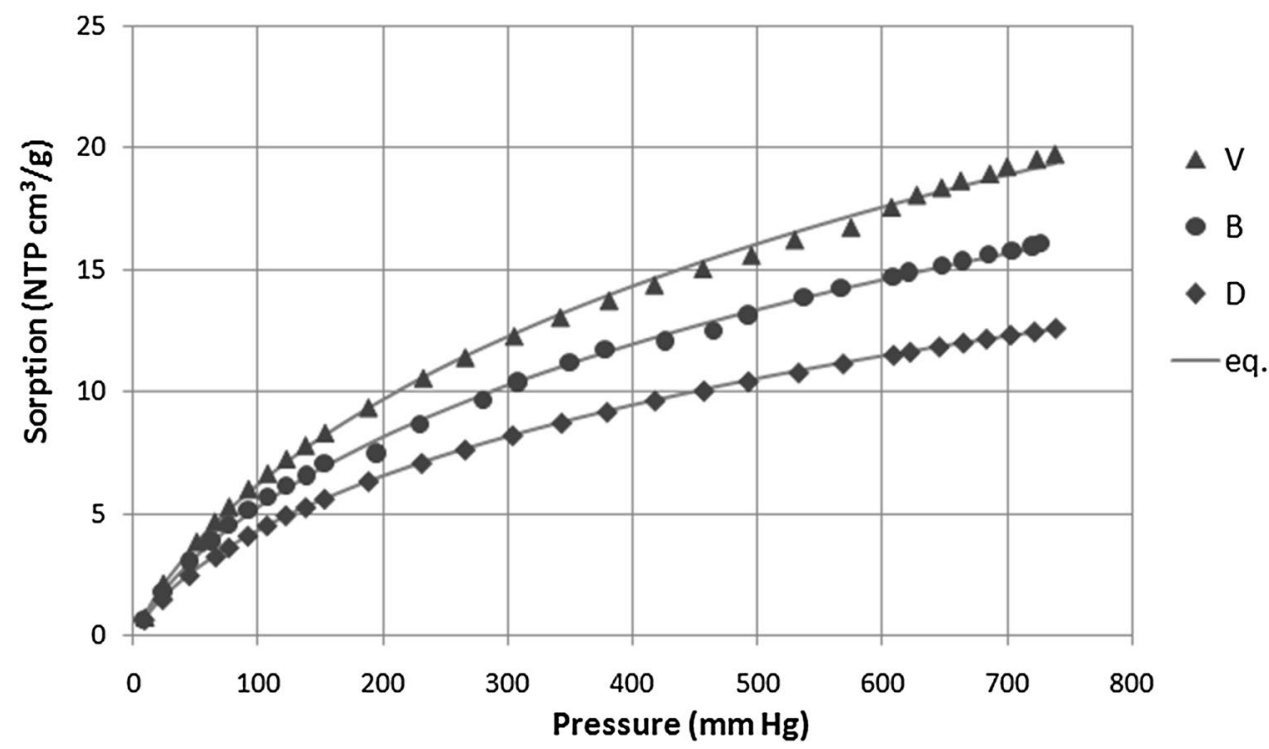

Table 5 The DubininRadushkevich equation parameters: $V_{0}$ and $\beta E$ and micropore structure parameters for samples under investigation

\begin{tabular}{lllll}
\hline & $\begin{array}{l}\text { Maximum volume of } \\
\text { adsorbed gas } \mathrm{V}_{0}\left[\mathrm{~cm}^{3} / \mathrm{g}\right]\end{array}$ & $\begin{array}{l}\text { Free energy of adsorp- } \\
\text { tion } \beta E[\mathrm{~J} / \mathrm{mol}]\end{array}$ & $\begin{array}{l}\text { Specific surface area of } \\
\text { micropores }\left[\mathrm{m}^{2} / \mathrm{g}\right]\end{array}$ & $\begin{array}{l}\text { Micropore } \\
\text { volume } \\
{\left[\mathrm{cm}^{3} / \mathrm{g}\right]}\end{array}$ \\
\hline $\mathrm{V}$ & 50.4 & 10.581 & 233.48 & 0.0936 \\
$\mathrm{~B}$ & 40.9 & 10.701 & 183.04 & 0.0733 \\
$\mathrm{D}$ & 30.9 & 10.897 & 141.56 & 0.0567 \\
\hline
\end{tabular}


researched by Mastalerz et al. (2008); sample TN presented by Zhao et al. (2016); samples of clarain and durain that are closed in composition to samples $\mathrm{V}$ and B, respectively, included in the work of Teng et al. (2017).

The high vitrinite concentrate display a larger hysteresis than the high inertinite concentrate and a lack of closure of the hysteresis loop (Fig. 4). Conventional mechanism of sorption hysteresis is related to the transition between metastable equilibrium states, which is induced by capillary condensation in mesoporous materials (e.g. Donohue and Aranovich 1998). However, the sorption hysteresis of carbon dioxide cannot be explained by capillary condensation because of two issues: the reservoir temperature of coal seams is in most cases greater than that of $\mathrm{CO}_{2}$ $(\mathrm{Tc}=304.2 \mathrm{~K})$ and coal has a polymeric structure with complicated porous system containing both micropores and mesopores (e.g. Bell and Rakop 1986). Wang et al. (2014) suggested a most likely explanation for mine gases, carbon dioxide and methane, sorption hysteresis. According to authors, coal contains constricted micropores with narrow pore throats which are smaller than the kinetic diameters of methane and $\mathrm{CO}_{2}$. The gas molecules can enter the constricted pores with increasing gas pressure, but this leads to swelling of the coal matrix which further narrows the pore throats. During depressurization, the gas molecules require more energy to escape the pores than that which enables them to enter the pores and the pore throats will be further narrowed due to embedded gas molecules during pressurization; this induces the different energies required for entering and escaping from the constricted pores, and thus causes the sorption hysteresis to occur and the presence of undesorbed gas.

The Dubinin-Radushkevich (D-R) equation was used for fitting the sorption data (Fig. 3). This traditional model was widely used to correlate experimental adsorption experiments on microporous adsorbents and is consider to be representative in this field. It treats coal as a rigid structure that does not change as a result of interaction with sorbed gas (Dubinin and Radushkevich 1947; Kapoor et al. 1989; Zhao et al. 2016) and is given here as:

$V=V_{o} \exp \left[-\left(\frac{R T}{\beta E} \ln \frac{p_{0}}{p}\right)^{2}\right]$

where $V$ is the volume adsorbed at relative pressure of $p_{0} / p$ at temperature $\mathrm{T}$, and $p_{0}$ is the $\mathrm{CO}_{2}$ saturated vapor pressure at temperature $T, V_{0}$ is the maximum volume of adsorbed gas, $E$ is the energy of adsorption, $\beta$ is the affinity coefficient of the adsorbate, $R$ is the universal gas constant, $T$ is the equilibrium temperature of gas adsorption. The $\mathrm{D}-\mathrm{R}$ equation is based on Polanyi's potential theory of adsorption and is adequate for adsorption of vapors on porous adsorbents in a wide range of pressure. It contains only two parameters: $V_{0}$ and $\beta E$ (Dubinin and Radushkevich 1947; Kapoor et al. 1989).

The D-R equation shows a very good agreement with the experimental data obtained for both lithotypes concentrates and basic coal under investigation (Fig. 3). The values of the maximum (saturated) adsorption amount calculated during the fitting of D-R equation differ between concentrates of lithotypes and basic coal and they are proportional to the values of sorption capacity obtained in the experiments (Table 5). Sample V with the high vitrinite concentration has a 23\% higher and sample D with the high inertinite concentration has a $24 \%$ lower saturation capacity than the basic coal sample. On the other hand the parameters corresponding to the free energy of adsorption are almost identical for
Fig. 4 Low pressure $\mathrm{CO}_{2}$ sorption and desorption isotherms of the original coal B and concentrates of vitrain $\mathrm{V}$ and durain $\mathrm{D}$

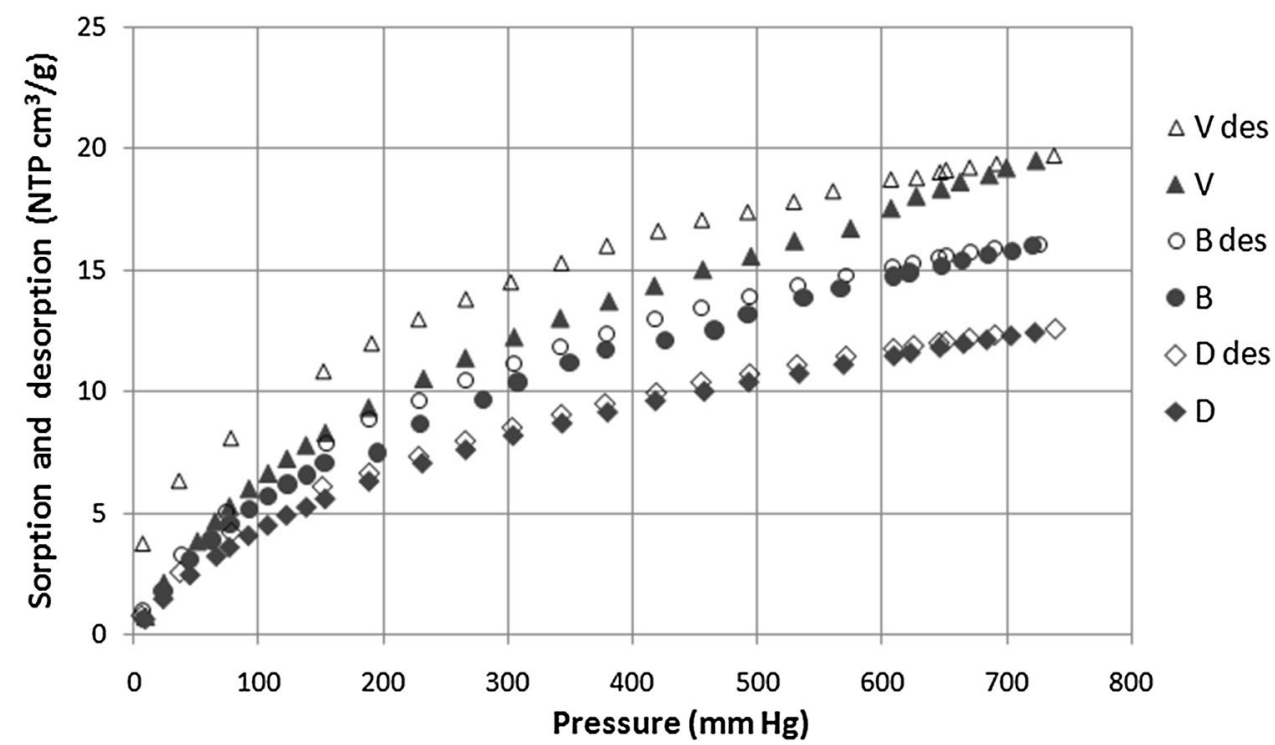


all samples under investigation (Table 5). The value for sample $\mathrm{V}$ is $1 \%$ higher and for sample $\mathrm{D}$ is $2 \%$ lower than the result obtained for basic coal. This indicates that the mechanism of carbon dioxide deposition in coal porous structure is the same in the case of macerals of vitrinite group and inertinite group.

\section{Conclusions and remarks}

1. Efficiency of separation process was verified by determining the maceral composition of lithotype concentrates and original coal. The results were sufficient and satisfactory.

2. Coal surface properties were evaluated via acidic functional oxygen groups content. The tests shown the decrease of amount of oxygen groups in inertinite rich concentrate confirming it to be least reactive. Opposite effect has been observed for vitrinite concentrate.

3. In comparison to swelling ratio of the original coal, the value determined for inertinite rich concentrate is lower by $18 \%$ and value obtained for vitrinite rich concentrate is higher by $170 \%$.

4. Further tests shown the increase of both helium and methanol densities for inertinite rich concentrate and the decrease for vitrinite concentrate. The density of coal depends on the content of elements in coal and elemental composition of individual macerals is relevantly different even in case of the same original coal.

5. The coal specific surface area of micropores and micropore volume increase from inertinite rich concentrate, through basic coal to vitrinite concentrate.

6. Adsorption capacity of $\mathrm{CO}_{2}$ on low rank coal under investigation depends on maceral composition and increases proportionally with the content of vitrinite.

7. The magnitude of sorption hysteresis corresponds with the vitrinite concentration in coal. The lack of closure of the hysteresis loop may be due to swelling of the coal during adsorption that induces the different energies required for entering and escaping of sorbate molecules from the constricted pores.

8. The Dubinin-Radushkevich (D-R) equation shows a very good agreement with the experimental data. The micropore volumes constant are proportional to those of sorption capacities. The parameters related to the free energy of adsorption have the same value for all samples.

Acknowledgment Financial support for this study was provided by AGH University of Science and Technology framework No. 16.16.210.476.

\section{Compliance with ethical standards}

Conflict of interest The authors declare that they have no conflict of interest.

Open Access This article is distributed under the terms of the Creative Commons Attribution 4.0 International License (http://creativeco mmons.org/licenses/by/4.0/), which permits unrestricted use, distribution, and reproduction in any medium, provided you give appropriate credit to the original author(s) and the source, provide a link to the Creative Commons license, and indicate if changes were made.

\section{References}

Baran, P., Czerw, K., Samojeden, B., Czuma, N., Zarębska, K.: The influence of temperature on the expansion of a hard coal-gas system. Energies 11, 2735 (2018)

Bell, G.J., Rakop, K.C.: Hysteresis of methane/coal sorption isotherms. SPE 15454. SPE 61st Annual Technical Conference. New Orleans, LA. (1986)

Bielowicz, B.: A new technological classification of low-rank coal on the basis of Polish deposits. Fuel 96, 497-510 (2012)

Busch, A., Gensterblum, Y., Krooss, B.M., Littke, R.: Methane and carbon dioxide adsorption/diffusion experiments on coal: an upscaling- and modeling approach. Int. J. Coal Geol. 60, 151-168 (2004)

Chalmers, G.R.L., Bustin, R.M.: On the effect of pertographic composition on coalbed methane sorption. Int. J. Coal Geol. 69, 288-304 (2007)

Clarkson, C.R., Bustin, R.M.: The effect of pore structure and gas pressure upon the transport properties of coal: a laboratory and modeling study. 1. Isotherms and pore volume distributions. Fuel 78, 1333-1344 (1999)

Donohue, M.D., Aranovich, G.L.: Adsorption hysteresis in porous solids. J. Colloid Interface Sci. 205, 121-130 (1998)

Dubinin, M.M., Radushkevich, L.V.: Equation of the characteristic curve of activated charcoal. Chem Zentr. 1, 875-890 (1947)

Goertzen, S.L., Theriault, K.D., Oickle, A.M., Tarasuk, A.C., Andreas, H.A.: Standarization of the Boehm titration. part I. $\mathrm{CO}_{2}$ expulsion and endpoint determination. Carbon 48, 1252-1261 (2010)

Ibarra, J., Muñoz, E., Moliner, R.: FTIR study of the evolution of coal structure during the coalification process. Org. Geochem. 24, 725-735 (1996)

Kapoor, A., Ritter, J.A., Yang, R.T.: On the Dubinin-Radushkevich Eqation for adsorption in microporous solids in the Henry's law region. Langmuir 5, 1118-1121 (1989)

Karacan, C.Ö., Mitchell, G.D.: Behavior and effect of different coal microlithotypes during gas transport for carbon dioxide sequestration into coal seams. Int. J. Coal Geol. 53, 201-217 (2003)

Lamberson, N., Bustin, R.M.: Coalbed methane characteristics of gates formation coals, Northeastern British Columbia: effect of maceral composition. Am. Assoc. Pet. Geol. Bull. 12, 2062-2076 (1993)

Larsen, J.W., Flowers II, R.A., Hall, P., Carlson, G.: Structural rearrangement of strained coals. Energy Fuel 11, 998-1002 (1997)

Mastalerz, M., Gluskoter, H., Rupp, J.: Carbon dioxide and methane sorption in high volatile bituminous coals from Indiana. USA. Int. J. Coal Geol. 60, 43-55 (2004)

Mastalerz, M., Drobniak, A., Strapoc, D., Solano, Acosta W., Rupp, $\mathrm{J} .:$ Variations in pore characteristics in high volatile bituminous coals: implications for coal bed gas content. Int. J. Coal Geol. 76, 205-216 (2008)

Mastalerz, M., Drobniak, A., Walker, R., Morse, D.: Coal lithotypes before and after saturation with $\mathrm{CO}_{2}$; insights from micro- and 
mesoporosity, fluidity, and functional group distribution. Int. J. Coal Geol. 83, 467-474 (2010)

Ndaji, F.E., Thomas, K.M.: Effect of solvent basicity on the kinetics of solvent swelling of coal. Fuel 72, 1531-1535 (1993)

O'Keefe, J.M.K., Bechtel, A., Christanis, K., Dai, S., DiMichele, W.A., Eble, C.F., Esterle, J.S., Mastalerz, M., Raymond, A.L., Valentim, B.V., Wagner, N.J., Ward, C.R., Hower, J.C.: On the fundamental difference between coal rank and coal type. Int. J. Coal Geol. 118, 58-87 (2013)

Radlinski, A.P., Mastalerz, M.: Neutron scattering study of vitrinite: insights into sub-micrometer inclusions in North American Carboniferous coals of bituminous rank. Int. J. Coal Geol. 186, 145-154 (2018)

Teng, J., Mastalerz, M., Hampton, L.B.: Maceral controls on porosity characteristics of lithotypes of Pennsylvanian high volatile bituminous coal: example from the Illinois Basin Int. J. Coal Geol. 172, 80-94 (2017)

Wang, K., Wang, G., Ren, T., Cheng, Y.: Methane and $\mathrm{CO}_{2}$ sorption hysteresis on coal: a critical review. Int. J. Coal Geol. 132, 60-80 (2014)
Zhang, W., Jiang, S., Wang, K., Wang, L., Xu, Y., Wu, Z.: Thermogravimetric dynamics and FTIR analysis on oxidation properties of low-rank coal at low and moderate temperatures. Int. J. Coal Prep. Util. 35, 39-50 (2015)

Zhao, J., Xu, H., Tang, D., Mathews, J.P., Li, S., Tao, S.: A comparative evaluation of coal specific surface area by $\mathrm{CO}_{2}$ and $\mathrm{N}_{2}$ adsorption and its influence on $\mathrm{CH}_{4}$ adsorption capacity at different pore sizes. Fuel 183, 420-431 (2016)

Zarębska, K., Dudzińska, A.: The possibility of $\mathrm{CO}_{2}$ storage in coal beds-verification of experimental data. Gospod. Surowcami Min. 24, 347-355 (2008)

Publisher's Note Springer Nature remains neutral with regard to jurisdictional claims in published maps and institutional affiliations. 